\title{
Karta Praw Podstawowych - jaki projekt społeczeństwa?
}

\author{
DOI: $10.35757 /$ CIV.2010.12.01
}

Karta Praw Podstawowych Unii Europejskiej ${ }^{1}$ obrosła od 2000 roku wieloma komentarzami i analizami, dotyczącymi zarówno prawnego charakteru tego dokumentu, jak i jego znaczenia społecznego oraz politycznego. $Z$ tego punktu widzenia zamysł niniejszego tekstu może się wydawać nie do końca na czasie. Chodzi mi bowiem o spojrzenie na Kartę jako na dokument projektujacy społeczeństwo europejskie, ale $z$ pozycji obserwatora, któremu obca jest instytucjonalna i polityczna historia Karty. Proponuje więc odtworzenie konstrukcji zawartej w Karcie takiej, jaka się ona jawi w swoim słownym wyrazie, w miarę możności bez prób wyjaśniania treści tej konstrukcji przez odwołanie do jej genezy. Będzie to zatem bardzo jednostronne potraktowanie Karty, uprzywilejowujące (z pewnością ze szkodą dla pełności analizy) jej aspekt słowny. Takie literalne interpretowanie dokumentów, zbliżone do analizy treści, wyszło zdaje się $\mathrm{z}$ mody $\mathrm{w}$ rozumowaniu prawniczym (w zgodzie zresztą $z$ duchem prawa europejskiego). Nie jest ono również zgodne $z$ bliskim $\mathrm{mi}$, rozumiejącym podejściem do przedmiotów kultury, które nakazywałoby uwzględnić w rozważaniach

Marta Bucholc - doktor socjologii, adiunkt w Zakładzie Historii Myśli Społecznej Instytutu Socjologii Uniwersytetu Warszawskiego, absolwentka Kolegium Miedzywydziałowych Indywidualnych Studiów Humanistycznych oraz Wydziału Prawa i Administracji Uniwersytetu Warszawskiego. Tłumaczka m.in. Czystości i zmazy Mary Douglas (2007) oraz Wyobraźni socjologicznej Charlesa W. Millsa (2007).

1 Dziennik Urzędowy UE 2007/C/303, s. 1. 
nad treścią dokumentu możliwie jak najszerszy, nie zaś najwęższy kontekst. Taka wąska, abstrahująca interpretacja ma jednak wiele istotnych zalet, na które pozwolę sobie krótko wskazać.

\section{Zalety literalnego odczytywania aktów prawnych}

Po pierwsze, rozumienie nawiązujacce do szerokiego kontekstu ma tę własność, że konstruuje ciagłość pomiędzy interpretowanym tekstem a innymi, postrzeganymi jako podobne do niego lub $z$ nim związane. Jest to oczywiście głęboko uzasadnione zwłaszcza w przypadku dokumentów urzędowych i aktów prawnych, które wiążą się ze soba rozmaitymi relacjami intertekstualnymi. $Z$ drugiej jednak strony może to utrudniać dostrzeżenie nowych warstw sensu oraz opóźnić intelektualna (i nie tylko) reakcję na nie, ponieważ, jak zauważył Michel Foucault w Archeologii wiedzy, umysł nastawiony na śledzenie wynikania i ciagłości $z$ trudem przestawia się na dostrzeganie innowacji i nieciagłości. Trudno zaś zaprzeczyć, że nieciagłość i innowacja, zwłaszcza w prawie, może mieć doniosłe konsekwencje.

Po drugie, interpretacja $\mathrm{w}$ duchu ciagłości nastraja interpretatora przychylnie do badanego tekstu. Interpretator, zrozumiawszy, skąd tekst się wziął w takiej właśnie postaci, skłonny jest dokonywać operacji podobnej do psychologicznej racjonalizacji także $\mathrm{w}$ odniesieniu do tych treści, które skądinąd wcale zrozumiałe nie sa. Jeśli na przykład wiemy, że takie a nie inne postanowienie Karty jest wynikiem kompromisu politycznego podyktowanego taka to a taką dyskusją światopoglądowa zakończona jakąś forma kompromisu, jesteśmy skłonni niejako przejść do porządku nad jego treścią. W ten sposób wyjaśnia się zreszta niekiedy nawet ewidentne i uznane słabości Karty, na przykład jej mało jurydyczny charakter, niekonkluzywność niektórych sformułowań czy brak jasnego rozróżnienia norm o odmiennym charakterze 
prawnym $^{2}$. Takie racjonalizacje moga zresztą się pojawić potem, choćby jako entymematyczne przesłanki rozumowania prawniczego, które owym kompromisowym postanowieniom będzie przypisało sens adekwatny do intencji stron kompromisu, tym samym całokształt okoliczności politycznych powstania aktu prawnego traktując jak wskazówkę oraz przesłankę w wykładni celowościowej i aksjologicznej. Taka skłonność do racjonalizowania uważam za potencjalnie groźna sama w sobie. Abstrahując jednak od tego, warto zwrócić uwagę na inna jej, znacznie bardziej niebezpieczna konsekwencję, która stanowi zarazem trzeci argument przemawiający za przydatnościa dosłownego interpretowania dokumentów, zwłaszcza tych ważniejszych.

Otóż kontekst powstania aktu prawnego $z$ zasady nie jest w owym akcie zapisany (mimo unijnej tradycji zaopatrywania aktów prawnych w rozbudowane preambuły, które zwykle podsumowuja różnorodne cele przyświecające danej regulacji i niejako wskazuja jej adekwatny zdaniem prawodawcy kontekst interpretacyjny, tym samym stanowiąc swoisty zestaw dyrektyw wykładni). Jest to o tyle uzasadnione, że charakter aktu normatywnego wymaga, by mógł on być stosowany przez pewien czas, zatem co najmniej możliwe jest, że ów adekwatny kontekst ulegnie zmianie. Odkontekstowienie aktu prawnego czyni go więc bardziej elastycznym i podatnym na zmiany sensu nieuniknione wobec dynamiki życia społecznego. Pamiętajmy jednak, że tekst (słowny wyraz zespołu norm) ogranicza potencjalne modyfikacje sensu, zakotwiczajac interpretacje. Odwracajac to rozumowanie, dochodzimy do wniosku, że interpretacja samych sformułowań aktu prawnego może dać pewne pojęcie o tym, ile pola dla zmiany pozostawia jego tekst, jakie kierunki interpretacji wydaja się przy aktualnym stanie języka wykluczone, a jakie prawdopodobne. Pamiętając o interpretacji literalnej, możemy się więc uodpornić zarówno na próby wczytywania w tekst nieadekwatnych treści, jak i na rozwój znaczeń tekstu

2 A. Nogal: Karta Praw Podstawowych Unii Europejskiej, „Civitas. Studia z Filozofii Polityki” 2002, nr 6, s. 116 . 
$\mathrm{w}$ rozmaitych kierunkach. To ostatnie staje się szczególnie istotne w przypadku aktów prawnych o długim okresie obowiazywania i dużej wadze (symbolicznej, politycznej, ekonomicznej itp.), stanowiących wskazówki dla stanowienia i stosowania innych norm. Można przyjąć, że kolejni użytkownicy aktu prawnego będą dalej mieli bezpośredni dostęp do samego tekstu (o ile będzie on dla nich wciąż zrozumiały w warstwie językowej), natomiast kontekst historyczny jego powstania będzie coraz odleglejszy i przez to coraz mniej pomocny w ustalaniu treści norm.

$\mathrm{Na}$ koniec warto dodać jeszcze jedna uwagę. Mimo że daleko odeszliśmy od idei przyjaznego prawa w duchu szwajcarskiego kodeksu cywilnego, nadal uważamy za ważne, by akty prawne mogły być rozumiane przez ludzi, których dotycza, a którzy powezma zamiar zapoznania się $z$ nimi. Otóż przeciętny obywatel, przystępując do lektury aktu prawnego, nie będzie się posługiwał aparatem krytycznym uwzględniajacym szeroki kontekst analizy, lecz własnym potocznym wyczuciem językowym, zdrowym rozsądkiem i elementarna logika oraz treściami kultury, z którymi ma do czynienia. Narzędzia te niekoniecznie musza otwierać przeciętnemu obywatelowi drogę do zrozumienia na przykład zasad wyceny pochodnych instrumentów finansowych przy ustalaniu poziomu ryzyka kredytowego przez banki, powinny jednak umożliwiać mu zapoznanie się $z$ zasadami porządku prawnego, w którym żyje. Wreszcie, odrzucając oręż specjalistycznej wiedzy, prawnik czy politolog może sprawdzić, jak się jawi znany mu tekst osobie, która takiej wiedzy nie posiada.

$Z$ nadzieją, że wyżej wymienione argumenty uzasadniają bardzo zawężony i ahistoryczny charakter rozważań, przejdę teraz do analizy reprezentacji wartości w Karcie.

\section{Trzy poziomy interpretacji}

Już struktura preambuły informuje o tym, jak postanowienia Karty sa postrzegane. Najpierw mamy więc listę „wspólnych 
wartości" narodów Europy. Drugi akapit preambuły wyjaśnia, że do owych „niepodzielnych, powszechnych wartości” należą „godność ludzka, wolność, równość i solidarność". Następnie otrzymujemy wskazówkę co do sposobu interpretacji tych wartości, mianowicie Unia "stawia jednostkę w centrum swych działań" oraz z tego właśnie względu stara się stworzyć „przestrzeń wolności, bezpieczeństwa i sprawiedliwości”, co stanowi już przejście do opisu sposobu działania Unii ukierunkowanego na wymienione poprzednio wartości. Celem Karty jest podtrzymanie wartości i działań Unii w ten sposób, że wzmocni się ochrona „praw podstawowych" (które pojawiaja się dopiero w tym miejscu) i staną się one „bardziej widoczne”. Ostatnie zdanie preambuly stanowi deklaracje „uznania” praw, wolności i zasad wymienionych w Karcie. Mamy więc do czynienia $z$ tekstem, który - dla socjologa - pełni trojaką rolę: artykułuje wartości, wyraża ich związek z praktykami (działaniami) i wywodzi $z$ tych wartości normy działania.

Każda $z$ tych relacji stwarza wiele interesujacych problemów, których wszystkich nie uda się tu zasygnalizować. Można jednak wskazać, o jaki mniej więcej typ problemów chodzi: Kto artykułuje wartości? Kto uznaje te wartości? Czy zachodzi podmiotowa tożsamość tego, kto wartości nazywa, i tego, kto je uznaje (czy jest to swoista aksjologiczna wykładnia autentyczna?) Jeśli nie, jaka jest relacja między tym, kto nazywa wartości a tym, kto je uznaje? (to mniej więcej pytania o to, jak rozumieć „Unia uznaje” w preambule). Jeśli chodzi o związek wartości z praktykami, pojawiaja się z kolei problemy w rodzaju: Czyje działania realizują wymienione wartości? Jeśli chodzi o organy władzy publicznej, czy działania te są w sensie Weberowskim „zorientowane na wartości”, czy też są działaniami przede wszystkim celoworacjonalnymi (na przykład legalnymi), a aksjologia jest $z$ ich punktu widzenia zewnętrznym uwarunkowaniem bez znaczenia dla ich sposobu funkcjonowania? Co do norm zaś: Kogo dotycza normy? Co na przykład znaczy przedostatnie zdanie preambuły: „korzystanie $z$ tych praw rodzi odpowiedzialność i nakłada obowiązki wobec innych osób, wspólnoty ludzkiej i przyszłych 
pokoleń"? Jeśli założyć, że korzystać z praw mają jednostki ([Unia] „stawia jednostkę w centrum swych działań), to na gruncie jakich wartości pojawia się związek między korzystaniem $z$ tych praw a odpowiedzialnościa i obowiązkami? Czy ma to wynikać $z$ samej natury wymienionych $\mathrm{w}$ Karcie wartości, $z$ jakich wynikaja prawa, czy też $z$ jakichś reguł, które wprost nie zostały w Karcie wyrażone? Czy odpowiedzialność jest, innymi słowy, zwiąana $z$ wartościami czy też z logiką funkcjonowania systemu, w którym te wartości maja być urzeczywistniane $\mathrm{w}$ ten sposób, że umożliwia jednostkom korzystanie $z$ określonych praw?

Wyżej wymienione pytania maja charakter w głównej mierze filozoficzny. Moga jednak zostać przeformułowane na problemy prawnicze, a także socjologiczne.

\section{Socjologiczne spojrzenie na Kartę}

Socjolog może analizować tekst taki jak Karta na kilku różnych płaszczyznach. Można między innymi postrzegać Kartę również jako wypowiedź, która ma wymiar projektujący. Takie spojrzenie byłoby bliższe socjologii wiedzy - chodzi o to, aby pokazać, jaki obraz rzeczywistości jest konstruowany w tekście Karty i za pomoca jakich środków (nie retorycznych czy stylistycznych, czyli czysto językowych, ale za pomoca jakich i jak ustrukturyzowanych odniesień do wartości). Należy przy tym pamiętać, że nawet jeśli tekst ma charakter deklaratywny („Unia uznaje”), to trzeba brać pod uwage jego performatywny charakter. Podobnie jak wszelkie dokumenty o podobnym charakterze Karta ustanawia reguły, których przestrzeganie ma doprowadzić do stworzenia (ewentualnie podtrzymania istnienia) społeczeństwa określonego rodzaju (wzmocnienia $\mathrm{w}$ istniejacym już społeczeństwie pewnych rysów, osłabienia innych, wyeliminowania pewnych elementów itp.).

Zapisy Karty odnoszące się do wartości moga więc w rozmaity sposób budować relację między społeczeństwem, które jest, a tym, 
które być powinno. Sązę, że funkcje te można by uporządkować, nawiąujac do schematu zaproponowanego przez Maxa Schelera $\mathrm{w}$ jego teorii światopoglądów ${ }^{3}$. Odniesienia do wartości zawarte w Karcie należałoby wówczas przyporządkować do trzech kategorii:

- społeczeństwo: światopogląd absolutnie naturalny;

- wspólnota: światopogląd względnie naturalny;

- wspólnota polityczna: światopogląd zasadzający się na wykształceniu.

\section{Społeczeństwo - światopogląd absolutnie naturalny}

Projektujące zapisy zawarte w Karcie moga, po pierwsze, wzmacniać poczucie jedności w zbiorowości ludzkiej, wskazując wartości niekwestionowane, które narzucaja kategorie, w jakich zbiorowość ta postrzega świat wokół siebie. Moga więc budować swoiście rozumiany Schelerowski światopogląd absolutnie naturalny - podstawę bytu danej społeczności - nie tylko w kategoriach ontologicznych, ale i epistemologicznych. Ta warstwa aksjologii może się odzwierciedlać w tekście w ten sposób, że będzie dostrzegalna tylko $z$ zewnattrz, jako zbiór najpierwotniejszych założeń, analogiczny do podstawowych ontologicznych założeń gier językowych w późnej filozofii Wittgensteina. Byłabym skłonna sądzić, że ta warstwa aksjologii konstruuje ze zbioru jednostek społeczeństwo, stanowiąc o odrębności i zasadności wyodrębnienia danej populacji jako samodzielnego podmiotu dyskursu, także politycznego ${ }^{4}$. Dla porządku należy oczywiście wspomnieć, że nie można

\footnotetext{
3 M. Scheler: Teoria światopoglądów, przekład S. Czerniak, A. Węgrzecki, w: idem: Pisma $z$ antropologii filozoficznej $i$ teorii wiedzy, Państwowe Wydawnictwo Naukowe, Warszawa 1987.

4 Por. Z. Stawrowski: Aksjologiczne podstawy konstytucji, „Civitas. Studia z Filozofii Polityki" 2007, nr 10, s. 9.
} 
wykluczyć ideologicznego wykorzystania tej warstwy aksjologicznej, czyli - najprościej mówiąc - przedstawienia (w jakimkolwiek celu) tego, co jest postulatem, jako rzeczywistości. Ta problematyką jednak zajmować się nie będę.

\section{Wspólnota - światopogląd względnie naturalny}

Kiedy już dostrzeżemy, że społeczeństwo jest ukonstytuowane na poziomie absolutnie naturalnego światopoglądu, można przystapić do analizy innych wartości rodzacych się na poziomie społeczeństwa, które $z$ kolei maja kreować wspólnotę (w sensie bliskim i Schelerowi, i Tönniesowi). Chodzi tu nie o wartości, które kształtuja sama percepcje świata - a zatem nie moga być przedmiotem refleksji ani rewizji ze strony zbiorowości, która jest ich nośnikiem - lecz o takie wartości, które, stanowiąc żywą treść przeżyć członków zbiorowości jako społeczeństwa, moga jednak być wyrażone, zrozumiane $\mathrm{i}$ wyartykułowane $\mathrm{w}$ polemice $z$ inna, jak to nazywa Scheler, „żywa tradycja” (innym habitusem). Ten poziom „wspólnoty" charakteryzuje się zaangażowaniem emocjonalnym, silnym zakorzenieniem $\mathrm{w}$ praktyce życia zbiorowego, pewnego rodzaju „niefalsyfikowalnościa” (jak sądzi Scheler, twory rozumu, takie jak nauka lub technika, moga być grabarzami tradycji, ale nie moga jej zgładzić; tradycja umiera, a dopiero jej śmierć pociaga za soba śmierć wszelkich wybudowanych na jej fundamencie wytworów kultury). Takie wartości byłyby tożsame $z$ Schelerowskim światopoglądem względnie naturalnym (nabytym w socjalizacji pierwotnej, bez własnej wiedzy i woli, mocą emocji i nawyku, nie zaś racjonalnej refleksji).

Dla porządku należy nadmienić, że wspólnota, o której tu mowa, może moim zdaniem, wbrew Schelerowi, być wewnętrznie zróżnicowana nie tylko pod względem strukturalnym, ale także kulturowym. Dla istnienia wspólnoty nie jest konieczne, by wszyscy jej członkowie mieli identyczny habitus, identyczne wartości i spo- 
sób widzenia świata. W obrębie wspólnoty moga istnieć wyodrębnione kulturowo i światopoglądowo części; wspólnota może być zróżnicowana wewnętrznie na poziomie głębszym niż tylko prosty podział pracy. Nie uznajac tego, nie wyjdziemy poza pojmowanie wspólnoty charakterystyczne dla pierwszych teorii zmiany społecznej i wszelkie dyskusje o wspólnocie w społeczeństwie wielokulturowym tracą sens. Jeśli więc założymy, że w obrębie społeczeństwa moga istnieć różne grupy mające własny światopogląd względnie naturalny, to twierdzę, że światopogląd względnie naturalny społeczeństwa (który czyni $z$ niego wspólnotę) może być nadbudowany na światopoglądach względnie naturalnych jej części (małych wspólnot wewnątrz społeczeństwa). Oczywiście pod warunkiem, że - wedle logiki właściwej każdemu $z$ tych partykularnych światopoglądów względnie naturalnych - światopogląd względnie naturalny całej wspólnoty może być $z$ nimi spójnie współprzeżywany.

\section{Wspólnota polityczna - światopogląd zasadzający się na wykształceniu}

Poza dwoma wyżej wymienionymi może istnieć trzeci poziom: to wartości, które nie są uznawane za „naturalne” w żadnym sensie, czyli sa przedmiotem dyskusji wewnątrz społeczeństwa. W każdym społeczeństwie mogą istnieć wartości, które są między jej członkami (ich grupami) sporne i nie są częścią światopoglądu względnie naturalnego całego społeczeństwa. Nie jest to samo w sobie, jak pisałam powyżej, przeszkodą dla istnienia wspólnoty. Dyskusje te mogą zresztą toczyć się pomiędzy wartościami przynależącymi do względnie naturalnych światopoglądów różnych grup żyjacych $\mathrm{w}$ społeczeństwie. Mimo że wartości światopoglądu naturalnego jako wartości przeżywane nie sa racjonalizowane i poddawane refleksji (nie szuka się dla nich uzasadnienia, bo nie jest ono potrzebne), nie wyklucza to rozmowy o wartościach prowadzonej w duchu Weberowskiej etyki odpowiedzialności. Nie jest to za- 
tem rozmowa, której celem jest ustalenie, jakie wartości powinny być uznawane (to bowiem, wedle poglądu, jaki uznaję, nie może być przedmiotem dyskusji, ale tylko deklaracji), lecz rozmowa, która problematyzuje wartości jako przesłanki działań (zarówno prywatnych, jak i publicznych, dotyczacych wspólnoty jako takiej). Można wręcz sądzić, że dopiero wspólnota opierająca się na ustaleniach aksjologicznych dokonanych nie tylko per facta concludentia w obszarze względnie naturalnego światopoglądu, lecz i świadomie przez jej członków, pozwala stworzyć warunki do tego rodzaju rozmowy o wartościach. Dopiero na gruncie wartości wspólnych można by więc rozmawiać o wartościach, które nas różnią.

$Z$ punktu widzenia Karty jako projektu ten pomysł jest o tyle istotny, że pozwala wskazać takie wartości i normy, które są sporne. Dla takich wartości można na potrzeby dyskusji poszukiwać uzasadnienia na rozmaitych poziomach. Najprawdopodobniej takie wartości sporne na poziomie (hipotetycznej) wspólnoty europejskiej mogłyby być wskazywane przez pozostawienie określonych kwestii legislacji krajowej (czyli normom wynikającym ze światopoglądów części wspólnoty). Ta kategoria wartości byłaby bliska ostatniemu, trzeciemu typowi Schelerowskiego światopoglądu, a mianowicie światopoglądowi opierającemu się (zasadzającemu się) na wykształceniu (Bildung, czyli też formowaniu, kształtowaniu; światopogląd ten tworzony jest i przyjmowany przez ludzi jako jednostki, a nie członków grup społecznych, moca intelektu i woli, a nie biernie kształtowanego nawyku). Na tym poziomie kształtuje się, jak sądzę, coś na kształt Tönniesowskiego stowarzyszenia o charakterze politycznym. Światopogląd dający podstawę takiej wspólnocie (czyli te wartości, co do których wspólnota uzgodni dyskursywnie, iż będzie je uważać za wspólne) nie jest naturalny, nie jest irracjonalny i przyswojony bezrefleksyjnie, ale - zdaniem Schelera - istnieje i zawiera wartości, które człowiek świadomie wybiera (przy czym naśladownictwo jest tu również wyborem). To jest to, co do czego ludzie moga się porozumieć, o ile istnieje między nimi więź zbudowana na współprzeżywaniu wspólnoty. 
Postanowienia Karty odnoszace się do tego poziomu wartości miałyby więc szczególną doniosłość „projektującą" (odnosiłyby się bowiem do postulowanych stanów rzeczy), byłyby dyskursywne (ponieważ każdy postulat $\mathrm{w}$ tym obszarze aksjologii jest głosem $\mathrm{w}$ dyskusji nad własnym uzasadnieniem), a $z$ punktu widzenia ulubionej $\mathrm{w}$ socjologii wiedzy problematyki ideologiczności ich status byłby nader złożony. $Z$ jednej bowiem strony byłyby one o tyle mniej podatne na ideologizację, że dyskusja nieuchronnie ujawnia ich przygodny charakter - uczestnictwo w dyskusji jest nierozerwalnie zwiazane $z$ doświadczeniem ironii. $Z$ drugiej jednak strony ideologizacja może być oczywiście wykorzystywana jako broń w dyskusji, jako dodatkowe narzędzie retoryczne (prezentujac coś jako istniejace, a zatem ustalone, niejako uodparniamy to na krytykę i przenosimy $z$ porzadku dyskursu w porzadek faktu). Samo zakreślenie obszaru dyskusji może zatem fałszować rzeczywistość na dwa sposoby: złudnie przedstawiać to, co nie jest dyskutowane, jako wspólne i naturalne, jak również na odwrót - złudnie problematyzować to, co skądinąd faktycznie jest wspólne i naturalne.

Podsumowując zatem, należy stwierdzić, iż postanowienia Karty, $z$ punktu widzenia analizowanej konstruktywistycznie aksjologii, moga się odnosić do projektu:

- społeczeństwa europejskiego (wspólnej, niedyskutowanej percepcji świata zbiorowości ludzkiej Europy);

- wspólnoty europejskiej (wspólnych wartości uznawanych przez to społeczeństwo i stanowiących, w sensie socjologicznym, rdzeń jego wspólnej kultury);

- europejskiej wspólnoty politycznej (wspólnoty dyskursu, w którym odmienne wartości moga się stać przedmiotem debaty).

Taką siatką pojęciową będę się posługiwać w dalszym ciagu. Nie omówię wszystkich postanowień Karty, bo większy pożytek przyniesie tutaj analiza węższa, a bardziej szczegółowa. Chciałabym zatem zająć się rozdziałem poświęconym „solidarności”. Jest to problem szczególnie bliski socjologowi, jedno $z$ pierwszych zagadnień badawczych, jakie postawili klasycy naszej dyscypliny, 
tym bardziej więc interesujące jest, jaką wizję solidarności europejskiej kreśli Karta.

\section{Solidarność spoleczna w Karcie}

Problematykę solidarności społecznej wprowadza przedostatnie zdanie preambuły, głoszace, iż „korzystanie $z$ [...] praw [podstawowych] rodzi odpowiedzialność i nakłada obowiązki wobec innych osób, wspólnoty ludzkiej i przyszłych pokoleń". Jak zatem widać, traktowanie jednostki jako najistotniejszego punktu odniesienia wiąże się $z$ przekonaniem, że jednostka $z$ kolei, korzystajac $z$ nadanych jej praw, staje się zarazem podmiotem obowiązów i odpowiedzialności wobec zarówno innych jednostek traktowanych $z$ osobna, jak i wobec wspólnoty ludzkiej, i to nie tylko istniejącej aktualnie, ale i rozciagającej się w czasie. Formuła ta, stosowana zresztą $\mathrm{w}$ wielu aktach prawa wspólnotowego, podkreśla zarówno uniwersalizm praw podstawowych, jak i ogólnoludzki pożytek $z$ ich posiadania choćby przez pewną część ludzkości (skoro ich posiadanie rodzi obowiąki wobec społeczności znacznie szerszej niż grono podmiotów tych praw). Jak widać, takie powiązanie praw i obowiązków nie jest więc oparte (w każdym razie nie bezpośrednio i nie przede wszystkim) na zasadzie wzajemności dorozumianej czy kontraktu, ale na pewnym wyobrażeniu natury samych tych praw.

Rozdział „Solidarność” pojawia się zatem w kontekście odpowiedzialności, która powinna działać między jednostkami, a wynika $z$ samej istoty praw podstawowych. Reguly tej odpowiedzialności należy umocnić i uwydatnić. Karta projektuje społeczeństwo, w którym nierozerwalny (i niekwestionowalny) jest związek między posiadaniem praw a odpowiedzialnościa i obowiązkami wobec zbiorowości. Nie ma praw jako wyizolowanego konstruktu - prawa i obowiazki sa wzajemnie swoimi korelatami. Nie sa jednak skorelowane $\mathrm{w}$ taki sposób, jak w umownym stosunku zobowią- 
zaniowym - niekontraktowość ujęcia wyraża się właśnie w tym, że obowiązki i odpowiedzialność zostają uogólnione na całą wspólnotę. Przypomina to socjologiczna koncepcję wymiany uogólnionej. Polega ona na tym, że jednostka udostępnia posiadane przez siebie zasoby jednemu $z$ członków sieci społecznej (który, $z$ kolei, oddaje je innym członkom itd.), a otrzymuje w zamian zasoby od innych, $z$ którymi nie weszła w bezpośrednią wymianę ${ }^{5}$. Jednostka działa więc $\mathrm{w}$ poczuciu obowiązku odwzajemnienia/udostępnienia zasobów, którego beneficjentem jest cała wspólnota. Za wykonanie tego obowiazku jednostka ponosi odpowiedzialność nie wobec innej jednostki, lecz wobec wspólnoty jako takiej, gwarantującej płynny przebieg wymiany. $Z$ punktu widzenia socjologa przejawia się to choćby $\mathrm{w}$ tym, że $\mathrm{w}$ razie niewykonania obowiązku jednostkę dotknie sankcja albo wewnętrzna (na przykład dyskomfort emocjonalny wynikajacy $z$ wyposażenia socjalizacyjnego), albo zewnętrzna, stosowana nie przez określonego pokrzywdzonego w wymianie partnera, lecz przez wspólnote jako taka. Taka koncepcja obowiąku prowadzi do konieczności włączenia problematyki odpowiedzialności jako uzupełnienia praw jednostkowych.

Wydaje się, że wszystko to do pewnego stopnia mieści się w klasycznej Kantowskiej tradycji etycznej, warto jednak zwrócić uwagę, że współzależność obowiązku, odpowiedzialności i uprawnień nie jest założeniem dyskursu Karty, lecz postulatem wyrażonym wprost, z którego wynikaja również pewne wyeksplikowane konsekwencje. Zatem za element światopoglądu absolutnie naturalnego należałoby tu uznać raczej przekonanie, że samo korzystanie $z$ praw jest naturalne dla ludzkiej jednostki. Natomiast zwiazane $z$ tym poczucie obowiąku byłoby już postulatem $z$ poziomu wspólnotowego, konstytuującego przeżywana wspólnie w Europie świadomość współodpowiedzialności za losy społeczeństwa. Europa chciałaby się $\mathrm{w}$ tym postulacie wyrazić, opowiedzieć swój projekt, którego niewypowiadana podstawa jest pojmowanie jako

${ }^{5}$ Por. J.H. Turner, J.E. Stets: Socjologia emocji, przekład M. Bucholc, Wydawnictwo Naukowe PWN, Warszawa 2009. 
oczywiste indywidualnych uprawnień i obowiązków wynikających $z$ Karty (co pośrednio wynika $z$ deklaracji „stawiania jednostki w centrum").

Twierdzę zatem, że rozdział poświęcony solidarności ma nieco inny charakter niż trzy pierwsze tytuły Karty (poświęcone prawom, wolności i równości), i opierając się na absolutnie naturalnym założeniu wyrażonym w sposób dorozumiany w preambule, w zdecydowanie większym stopniu wyraża przede wszystkim projekt wspólnoty (czyli projekt $z$ drugiego poziomu, poziomu światopoglądu względnie naturalnego). Kierunek działania postanowień tytułu IV jest zdecydowanie poziomy (nie w sensie prawniczym rzecz jasna, lecz $\mathrm{w}$ tym, że zapewnienie określonych uregulowań na poziomie wspólnotowym bądź krajowym ma doprowadzić do określonego stanu stosunków międzyludzkich, który to zamiar znajdujemy zreszta już w rozdziale $\mathrm{III}^{6}$ ). Efekt pionowy ma tu zadziałać jako bodziec dla zmiany wzajemnego podejścia ludzi do siebie w kilku wyodrębnionych obszarach życia.

Rozdział poświęcony solidarności obejmuje dwanaście artykułów, z których pięć odnosi się do szeroko pojętych stosunków pracy, jeden do pracy dzieci i osób młodocianych ${ }^{7}$, jeden do relacji między życiem rodzinnym i zawodowym. Zatem siedem artykułów mówi o pracy i społecznych skutkach pracy, a jeden porusza tematykę pokrewna (zabezpieczenia społecznego i pomocy socjalnej). Żaden inny obszar stosunków społecznych nie budzi takiego zainteresowania w kontekście solidarności. Pojawia się problematyka ochrony zdrowia, dostępu do usług świadczonych w ogólnym interesie gospodarczym, ochrony środowiska i ochrony konsumentów. Należałoby również $\mathrm{w}$ kontekście tych zasad dotyczących solidarności czytać postanowienia art. 9 (prawo do zawarcia małżeństwa i wychowania rodziny), art. 15 (wolność wyboru zawodu i prawo

\footnotetext{
6 Por. A. Nogal: Karta..., s. 111, na temat wyrównywania faktycznych nierówności.

7 Na uwage zasługuje oczywiście nie samo zamieszczenie w Karcie tych postanowień, powtarzajacych ustalenia wspólnotowe i miedzynarodowe w zakresie praw socjalnych i pracowniczych (por. ibidem, s. 112), ile raczej ich związek z solidarnością społeczna, wpływający na interpretację tej wartości.
} 
podejmowania pracy) oraz 24 (prawa dziecka) i 25 (prawa osób $\mathrm{w}$ podeszłym wieku). Schemat jest czytelny - pewne prawa zostały jednostce zapewnione, natomiast tytuł o solidarności wskazuje, jaki powinien być stan stosunków społecznych (gwarantowany odpowiednimi uregulowaniami prawnymi), który zapewniłby przestrzeganie tych praw $\mathrm{w}$ rozmaitych obszarach życia.

$Z$ tego punktu widzenia istotne wydaje się, że spośród wymienionych artykułów $\mathrm{w}$ tym tytule wszystkie (poza ochrona zdrowia) dotycza sfery ekonomicznej czy - bardziej precyzyjnie - sfery działalności gospodarczej. Normy solidarności dotycza pracy (czyli sfery, w której pojawia się antagonizm między pracownikiem a pracodawca, antagonizm ów może się ujawniać na poziomie warunków pracy i płacy, wymiaru czasu pracy, zwolnień, ograniczeń tego, kto może być pracownikiem czy na przykład dyskryminacji płacowej itp.), relacji między rodziną a pracą zawodową (czyli konfliktu między wartościami pozaekonomicznymi a ekonomicznymi, w której [art. 33] praca i życie rodzinne sa prezentowane jako ewidentnie antagonistyczne względem siebie, a słabsza strona w sporze jest rodzina, która trzeba chronić przed zakusami pracy zawodowej). Również regulacja zabezpieczenia społecznego wyraźnie nawiązuje do takich rozwiązań, które nie pozwolą rynkowi pracy wypchnąć i wykluczyć osób nie mogących $z$ jakichkolwiek względów pracować lub nie uzyskujących dzięki pracy środków „wystarczających", czyli zgodnych z ogólnospołecznym (na poziomie wspólnoty) modelem życia. Katalog potencjalnych ubogich i wykluczonych koresponduje $z$ katalogiem praw (matki, chorzy, ludzie starsi lub tracacy pracę, czyli potencjalni bezrobotni). Również ochrona środowiska w tym samym kontekście rysuje się (podobnie jak na przykład w dokumentach Unii Europejskiej poświęconych społecznej odpowiedzialności biznesu czy w projektach $z$ nurtu ekonomii społecznej) jako przejaw polityki zrównoważonego rozwoju, czyli hamowania praktyk gospodarczych, które mogłyby źle wpływać na środowisko jako coś przekazywanego „przyszłym pokoleniom" w duchu współodpowiedzialności. Tak samo wygląda 
kwestia praw konsumentów. W literaturze podnosi się wprawdzie słusznie, że status kontraktowy konsumenta (jako homo oeconomicus passivus) i przedsiębiorcy jest nierówny, zatem regulacje prawa konsumenckiego chroniące prawa konsumenta wyrównuja tę dysproporcję ${ }^{8}$. Niemniej pozostaje faktem, że ochrona praw konsumentów ogranicza zakres swobody przedsiębiorców w relacjach $z$ konsumentami, zapobiegając nieuczciwym praktykom, mogącym wynikać $z$ dążenia do zysku, które jest sensem działalności gospodarczej, ale nie życia we wspólnocie.

W gruncie rzeczy, stosujac do tych postanowień poprzednio przedstawiona siatkę analityczna, otrzymujemy wniosek, że poziom dorozumianych (niewyrażonych) założeń tytułu o solidarności obejmuje przekonanie, iż działalność gospodarcza jest domena działań jednostkowych i nakierowanych na interes jednostki, który nie jest zgodny $z$ interesem wspólnoty oraz powinien być hamowany. Byłby to skądinąd interesujący argument $\mathrm{w}$ dyskusjach nad charakterem Karty.

Powyższe rozumowanie prowadzi do jeszcze jednego wniosku. Jak już stwierdziłam, za przekonaniem, że prawa przysługuja jednostce, ewidentnie nie idzie myśl, że równie naturalne i oczywiste jest, iż jednostka ze swoich praw wywodzi owo uogólnione na cała wspólnotę poczucie odpowiedzialności. Mechanizm ten nie ma więc opierać się na tym, że tak właśnie rozumieja swoje prawa ich podmioty i beneficjenci. Jeśli gospodarkę wolnorynkowa potraktujemy jako przejaw najdalej posuniętego indywidualizmu, to rozdział o solidarności należy czytać jako projekt norm, które miałyby taka postawę ograniczać. Jest to dodatkowy argument przemawiajacy za tym, że o ile indywidualizm i przekonanie, że trzeba go ograniczać $\mathrm{w}$ imię dobra wspólnoty, sa $z$ porządku absolutnie naturalnego, o tyle postulaty solidarności społecznej to już projektowanie wspólnoty względnie naturalnej. I - przechodząc do zakończenia - jest to projektowanie nie na poziomie politycznym (debaty o war-

\footnotetext{
8 Por. E. Łętowska: Europejskie prawo umów konsumenckich, C.H. Beck, Warszawa 2004.
} 
tościach), lecz projektowanie abstrahujące od poziomu światopoglądu zasadzającego się na wykształceniu i operujące wyłącznie na poziomie względnie naturalnej wspólnoty.

\section{Zakończenie - gdzie rozmawiać o solidarności społecznej w Unii Europejskiej?}

Tekst rozdziału IV Karty Praw Podstawowych jest poświęcony solidarności, ale dla socjologa jest to solidarność rozumiana stosunkowo wąsko i minimalistycznie. Jeśli solidarność kojarzyć $z$ więzią społeczna, watek ograniczania indywidualizmu, zwłaszcza gospodarczego, jest oczywiście istotny dla jej podtrzymywania ${ }^{9}$, nie jest jednak jedyny ani wystarczajacy. Wspólnotę światopogląu względnie naturalnego powinno konstytuować coś więcej: coś pozytywnego, nie zaś tylko zbiór ograniczeń chroniących prawa jednostkowe. Problem nie leży tu moim zdaniem w indywidualistycznym traktowaniu owych praw. Chodzi raczej o to, że nie widać w Karcie związu między solidarnościa a poziomem polityczności, co wydawałoby się wskazane, skoro na poziomie wspólnoty mamy do czynienia tylko z projektem. Solidarność społeczna Europy taka, jaka znajdujemy w Karcie - nie ma wymiaru politycznego. Karta nie zawiera na przykład żadnego wskazania, że uczestnictwo we wspólnych instytucjach mogłoby konsolidować społeczeństwo i czynić $z$ niego jedność. Konsolidacja i budowanie solidarności odbywaja się na zasadzie negatywnej. Nie ma tu sygnału debaty politycznej i nie ma wspólnoty, która mogłaby ja prowadzić. Projektowana wspólnota jest de facto rozumiana negatywnie (jest to zbiór ludzi, którzy sa poddani wspólnym normom w wykonywaniu uprawnień, które przysługuja im jako jednostkom $z$ racji bycia jednostkami, a nie jako członkom całości, chyba że o tyle, 9 Na temat zainteresowania Durkheima ta kwestia por. J. Szacki: Historia myśli socjologicz-
nej, Wydawnictwo Naukowe PWN, Warszawa 2002, s. 386. 
że akurat ta całość im je bez ich udziału nadaje). Tytuł o solidarności jest więc wyraźnie apolityczny (zwłaszcza w sensie Weberowskim $^{10}$ ). Wypadałoby więc podsumować te rozważania konstatacja, że - wbrew preambule - tekst Karty wskazywałby na brak konsensu (wspólnej żywej tradycji) w sferze solidarności społecznej oraz brak przekonania o potrzebie prowadzenia dyskusji w tym przedmiocie (lub, co na jedno wychodzi, o możliwości osiagnięcia konsensu w tej kwestii).

\footnotetext{
${ }^{10}$ Por. P. Marczewski: Szlachetny nihilizm a klasyczne pytania filozofii polityki. Rozróżnienie na fakty i wartości $w$ myśli politycznej Maxa Webera, "Civitas. Studia z Filozofii Polityki” 2007, nr 10, s. 204 i nast.
} 